\title{
Global Strategy, Local Action with Biogas Production for Rural Energy Climate Change Impact Reduction
}

\author{
A. S. Momodu, E. F. Aransiola, T. D. Adepoju, and I. D. Okunade
}

\section{Contents}

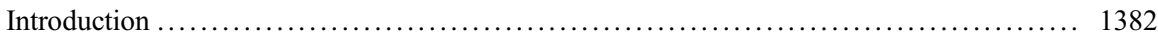

Literature Review . . . . . . . . . . . . 1383

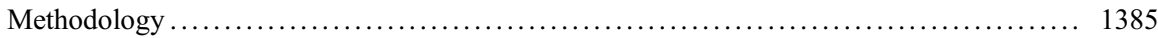

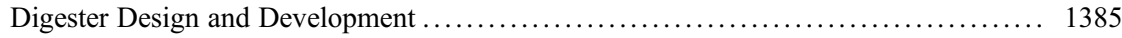

Up-Scaling Biogas Production from Laboratory Experiment ..................... 1386

Avoided Emission Calculations/Climate Change Impact Reduction ................ 1388

Estimation of Life Cycle Costs and Return Streams ............................ 1388

Business Model Formulation ............................................. 1389

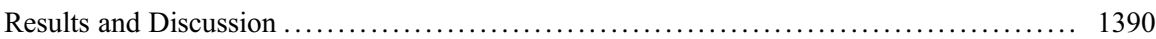

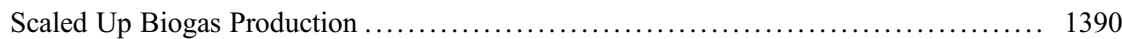

Avoided Emissions ......................................................... 1391

Investment Cost and Variable Cost Stream ................................. 1392

Life Cycle Costs and Return Streams .................................... 1392

Business Model Formulation .......................................... 1393

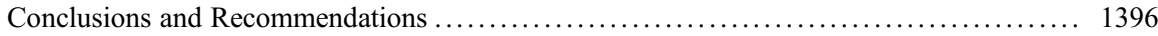

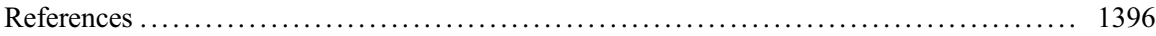

\section{Abstract}

Global climate change impact is predicted to affect various sectors including the energy demand and supply sectors respectively. Combating this impact will require adoption of both global strategy and localized actions. The use of low

This chapter was previously published non-open access with exclusive rights reserved by the Publisher. It has been changed retrospectively to open access under a CC BY 4.0 license and the copyright holder is "The Author(s)". For further details, please see the license information at the end of the chapter.
A. S. Momodu (西)
Centre for Energy Research and Development, Obafemi Awolowo University, Ile-Ife, Nigeria
E. F. Aransiola · T. D. Adepoju · I. D. Okunade
Department of Chemical Engineering, Obafemi Awolowo University, Ile-Ife, Nigeria 
carbon strategy based on renewables is a global strategy, while waste management of biodegradable materials through the use anaerobic technology to meet energy demand is a local action. Nigeria is among the vulnerable countries to global climate change impact; this is even more aggravated by its dependence on fossil fuel usage as well as poor waste management, which two, contribute significantly to greenhouse gas emissions. This chapter presents analysis of purified compressed biogas production, a waste conversion option, as a local action to meet rural household energy demand and contribute to global strategy of reducing climate change impact. It discusses both technical and business model approaches to upscale a laboratory experimental procedure for biogas production through anaerobic digestion using vegetal wastes. It shows that using anaerobic technology can achieve efficient waste management and at the same time generate energy that can be used to achieve avoided emissions for climate change impact reduction. The study also concludes that upscaling the project will be sustainable for rural energy augmentation as it produces clean and renewable energy, reduces the use of fossil fuels, provides jobs for skilled and unskilled labor, and generates new return streams.

\section{Keywords}

Global strategy - Local action - Waste management · Anaerobic technology · Rural households $\cdot$ Avoided emissions $\cdot$ Business model

\section{Introduction}

Energy is a very crucial input for attaining sustainable development. This has become even more pronounced for growth-driven economies, as those in developing countries as Nigeria. Most energy inputs driving economic activities are currently derived from fossil origin, principally hydrocarbon and solid fuels as firewood. These are not socially, environmentally, and economically efficient and therefore not sustainable. Fossil fuels contribute significantly to greenhouse emissions (Bölük and Mert 2014), while solid fuels produce indoor air pollution (WHO 2015). On the other hand, waste is produced from unwanted and discarded materials of human society (Bharadwaj et al. 2015), which needs to be managed properly. Management of waste is a global phenomenon (Isiaka 2017), although the challenge is more pronounced in developing countries for three reasons. These are the increased generation of waste due to increased population, improved living standards, technical and human capacity limitations (Guerrero et al. 2013). African countries are now faced with huge amounts of municipal waste, which has a direct effect on human health, safety, and environment (Bello et al. 2016). Although there is a paucity of data on waste generated annually in Nigeria, however, Isiaka (2017) reports that about 3 two million tons of waste are generated annually, while Vanguard (2017) reports a value of 24 million tons. Of these, only about $20-30 \%$ is collected with vegetal wastes, making up 65\% of those collected (Isiaka 2017; Ogwueleka 2009). 
Vegetal matter refers to substances produced by plant or growing in the manner of plant that can be decomposed by microorganisms. Significant contribution to greenhouse gases and volatile organic compounds emissions comes from their high moisture, organic contents, and biodegradability (Sridevi and Ramanujam 2012). Nonetheless, converting this resource properly could contribute to sustainable energy provision, which Nigeria is in dire need of. Anaerobic digestion is a technology that is recognized to be useful for converting vegetal and animal wastes to generate renewable energy in the form of biogas and organic fertilizer (Arsova 2010). This could result in saving the environment from further degradation, supplementing the energy needs of the rural population (Ahmadu et al. 2009), and generate extra returns streams for farmers and investors (Twidell and Weir 2005; Aransiola et al. 2014; Budzianowski and Brodacka 2017). This contributes significantly to the circular economy in rural communities (Jun and Xiang 2011). Vegetal matters usually occur in large quantities, making it difficult to dispose of easily; over time, this tend to make them become a source of harmful and offensive substances in landfills due to their decomposing qualities (Misi and Forster 2002).

The deployment of a co-digested anaerobic process using cow rumen as inoculum as local action for climate change impact reduction is reported. Essentially, the study involves the design and fabrication of stainless steel farm tanks for anaerobic bio-digestion; upscale of laboratory experimental data for feedstock loading to produce biogas from the substrate; estimate of avoided emissions compared to other fuel sources for cooking energy; evaluate life cycle costs and return streams of biogas produced based on different scenarios; and formulate a business model.

\section{Literature Review}

In biogas production, specificity of the substrate collected usually has effects on the type of digester to be used (Christy et al. 2013). Furthermore, biodigester systems are classified based on the method of feeding and number of reactors, with the method of feeding being either batch or continuous, while the number of reactors could also either be a single stage or multi stage (Brown 2006).

The single-stage process involves three stages of the anaerobic process occurring in one reactor. In this process, fermentative bacteria rate of growth is faster than that of acetogenic and methanogenic bacteria (Brown 2006). The consequence is that it results in acid accumulation, $\mathrm{pH}$ falling, and methanogenic bacteria growth. For the multi-stage processes, two or more reactors are used to space out the acetogenesis and methanogenesis stages that serve as filters in the system and thus enhancing the digester's production efficiency (Manyi-Loh et al. 2013).

During batch experimental setup, feeding of the digester is only done once, which is at the beginning of the reaction, with the products of the digester being collected at the end of each cycle. However, in that of the continuous system, the feeding and discharging of organic material is continuous (Levenspiel 1999). Rajendran et al. (2012) reviewed different household digesters which are commonly used, reporting that fixed dome (cylindrical digesters) are most commonly used type of digester in 
China, while the floating drum digesters are those highly recognized in India, with other digester types used being majorly tubular such as portable plug flow digesters. In terms of features, fixed dome digesters made up of the feed and digestate pipes, a fermentation chamber and a fixed dome on top of the biogas storage, while floating drum digesters are recognized for the floating drum to be at the top of the digestion chamber which separates the gas production and discharge (Neba et al. 2020). Plug flow digesters, which can operate as a household or an industrial digester, have a simple flow pattern without back-mixing. The presence of serious floating tendencies may cause clogging of the flow and prevent the escape of produced biogas in plug flow digesters, though, an inclined plug flow digester at an angle $45^{\circ}$ is a better option (Ziyan and Xiaohua 2014; Rajendran et al. 2012). A major advantage the plug flow digester has over fixed dome and floating drum digesters is that there is no difficulty in moving an installed digester, as it is able to produce biogas at a variable pressure and constant volume. In addition, plug flow digesters are capable of managing waste with the range of 11-13\% solid concentration (11-13\%) (Roos et al. 2004), being always operated in the mesophilic temperature range (Krich et al. 2005).

Global climate change impact is predicted to affect energy sector as with other key sectors of the economy (Arent et al. 2015). One of the strategic approaches to addressing the future of climate change impact is the use of low-carbon energy sources (Yadoo and Cruickshank 2012). Renewables have been taunted as a major contributor to this strategy (Solaun and Cerdá 2019). Developing countries like Nigeria are quite vulnerable to climate change impact, with energy sector being one of the most vulnerable (Ogundipe et al. 2014). Schaeffer et al. (2012) did an extensive review of the vulnerability of the energy sector to climate change. The paper reported on the vulnerability of biofuels to climate change. In addition, as regards biogas production in rural setting, there are ranges of challenges to be considered, which are well documented in literature (Madriz-Vargas et al. 2018). These challenges can affect the operational outcome of renewable energy (RE) technologies as well as the sustainability of the project as a whole. These issues raise questions as regards the set of community capabilities required, appropriate project design, and enabling an external environment for sustainable community RE (CRE) projects.

To introduce the use of biogas as a low carbon strategy to energy generation in the rural areas, the use of user-centered design concept (Redström 2006) is introduced. This approach was proposed as a means to scale-up the process of developing biodigesters in rural areas for energy generation. The essence of the concept is that it takes user experiences into consideration (Redström 2006) in its design. Thus, the basic concept of the business model formulation of the RE power system is to make it be owned, operated, or maintained by a community organization. With this, technical and nontechnical problems such as the issue of social integration of RE technologies, lack of investment and maintenance capabilities, as well as end-user education (Madriz-Vargas et al. 2018; Margolis and Zuboy 2006) are eliminated. 


\section{Methodology}

This section describes the approach adopted to design and fabricate the digesters, upscaling the substrate used to feed the digesters from a laboratory experiments (Adepoju 2019) conducted. The scaling up includes technical design and development of the biodigester, up-scaling biogas production from laboratory experiment, evaluation of avoided emissions, estimation of life cycle costs as well as return streams, and business model formulation.

\section{Digester Design and Development}

In the design, fabrication, and construction of the plug flow biodigester, the factors that affect the building of digester for optimum biogas yield (Jiang et al. 2011) should be taken into consideration. The principal materials to be selected for the fabrication will be stainless steel sheets because of its durability and as well as its ability to absorb heat easily, which improves mesophilic anaerobic digestion as to when compared to cement and block. The design analysis includes the design specification of the biodigester and the length of the digester is $5.96 \mathrm{~m}$. The required length-to-width will be within the ratio of 3.5:1 based on the Natural Resources Conservation Service (2004) length-to-width ratio for manure in plug-flow digesters. Therefore, the dimensions of the digester are:

Length of the digester $(\mathrm{L})=5.96 \mathrm{~m}$

Width of the digester $(\mathrm{W})=0.71604 \mathrm{~m}$

The volume of the digester $=9.6 \mathrm{~m}^{3}$

A plug flow reactor has the following components as shown in Fig. 1:

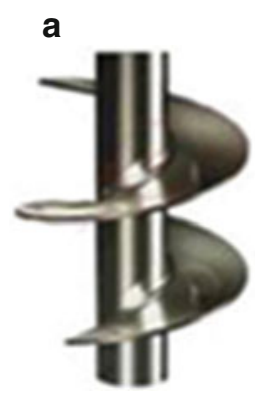

Screw type b

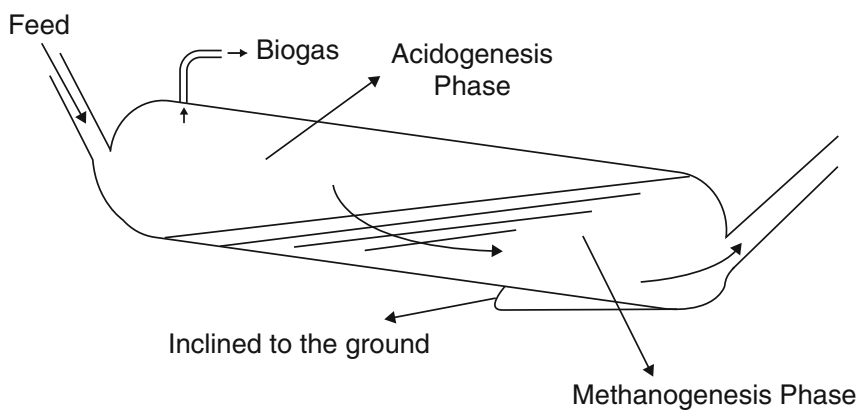

Stirrer Schematic diagram of a plug flow digester

Fig. 1 Schematic diagram of a plug flow digester 
Table 1 Theoretical comparison of different substrates to meet energy needs of 100 households

\begin{tabular}{l|l|l|l|l}
\hline & $\begin{array}{l}\text { Biogas } \\
\text { potential } \\
(\mathrm{L} / \mathrm{kg})^{\mathrm{a}}\end{array}$ & $\begin{array}{l}\text { Expected daily biogas } \\
\text { production needed for } \\
100 \text { households }\left(\mathrm{m}^{3}\right)\end{array}$ & $\begin{array}{l}\text { Expected biomass } \\
\text { (waste) for feeding } \\
(\text { tonnes })\end{array}$ & $\begin{array}{l}\text { Expected size } \\
\text { of biodigester } \\
\left(\mathrm{m}^{3}\right)\end{array}$ \\
\hline $\begin{array}{l}\text { Vegetal } \\
\text { matter }\end{array}$ & 70 & 39.13 & 133.91 & 67 \\
\hline $\begin{array}{l}\text { Corn } \\
\text { silage }\end{array}$ & 200 & 39.13 & 465.83 & 23 \\
\hline $\begin{array}{l}\text { Grass } \\
\text { silage }\end{array}$ & 220 & 39.13 & 423.48 & 21 \\
\hline
\end{tabular}

${ }^{a}$ Source: Arora and Linton (2011)

1. Inlet and outlet pipes: The inlet pipe can also be referred to as the feed pipe while the outlet pipe as the digestate pipe. The pipes to be used will be of a steel rod with diameters of $500 \mathrm{~cm}$ and $250 \mathrm{~cm}$ as the inlet for feeding the substrate into the digester and outlet pipes for discharging the consumed slurry at the end of the digestion, respectively. The inlet pipe which will be at an angle of $45^{\circ}$ for convenient channel of the substrate into the digester and the entry will be closed to prevent air from getting to the residue for easy break down of waste materials in the digester.

2. Stirrer: A screw-type, stainless material stirrer is shown in Fig. 1. The stirrer will be connected to a motor to drive it in order to create a turbulent motion of the substrates.

3. Storage tank: The storage tanks will be balloons made from high density polyethylene (HDP) or floating tank made from fiber glass for collection of biogas produced.

4. Effluent collection tank: The effluent (digestate) will be collected in a plastic tank.

The design involves the construction of seven $9.6 \mathrm{~m}^{3}$ biodigesters. A combination of the seven farm tanks biodigesters was designed to produce approximately $39.13 \mathrm{~m}^{3}$ of biogas daily. It is also expected that for each biodigester, about $64 \%$ of the biodigester size would be for gas accumulation. Table 1 shows different substrates with their biogas potentials, expected daily biogas production needed for 100 households, expected biomass feedstock, and expected size of biodigester. The use of grass silage as substrate for biogas production required the least sized digester at $21 \mathrm{~m}^{3}$.

\section{Up-Scaling Biogas Production from Laboratory Experiment}

This section describes up-scaling the steps to the pilot scale from laboratory experiment. The laboratory experiment involves the use of portable 201 plastic containers, modified as digesters, as shown in Fig. 2. Gas collection was done through water displacement method (Otun et al. 2015). Stirring was done by shaking the biodigester to prevent thickening and settling of the slurry. The experiment consists of the use of fresh waste samples of vegetables and fruits serving as feedstocks, and 
Fig. 2 Laboratory-scale experiment (Adepoju 2019)

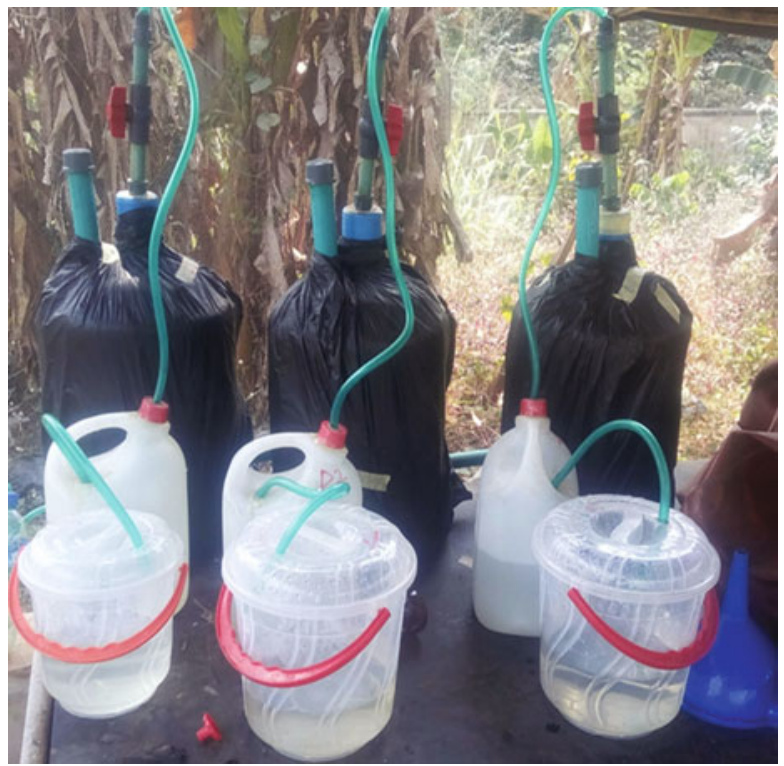

cow rumen fluid used as inoculum, collected from a food market and an abattoir. The vegetables and fruits, made up of watermelon, tomatoes, and oranges, were grinded to increase the surface area. The cow rumen fluid collected in polyethylene bags was stored at room temperature for 4 days (Elhasan et al. 2015). These were mixed with water to form slurry in the biodigester (Budiyono et al. 2014). Fresh vegetal wastes $(\mathrm{V})$ mixed with cow rumen fluid $(\mathrm{R})$ and clean water $(\mathrm{W})$ in different $\mathrm{V}: \mathrm{W}: \mathrm{R}$ ratio and batch fed into the digester. The retention time was 30 days.

The biodigester was scaled up based on the data acquired from the laboratoryscale experiment to meet the energy needs of about a hundred (100) rural households. The energy cooking need was estimated based on Riuji (2005) and Rea (2014) that 1001 of biogas will produce 23 min of cooking time. It was assumed that a household of 5 will use 3901 of biogas for 90 min cooking time in a day. With these data, it was estimated that 100 households will require 39,130 1 of biogas daily. According to Arora and Linton (2011), $1 \mathrm{~kg}$ of vegetal waste will produce on average 2.331 of biogas daily and a total of 701 biogas over a retention time of 30 days. From Arora (2011), to achieve a daily production rate of 39,130 1 of biogas, will require $16,670 \mathrm{~kg}$ of vegetal waste without the use of inoculum, requiring an organic loading rate (OLR) of $555.67 \mathrm{~kg}$ daily. With the use of cow rumen as inoculum, the efficiency of the substrate is improved by $26 \%$ (Stan et al. 2018), reducing the amount of vegetal matter needed to $13,310 \mathrm{~kg}$ or an OLR of $443.67 \mathrm{~kg}$ daily. The size of the biodigester is dependent on the amount of waste needed. Using the laboratory experiment that requires $4 \mathrm{~kg}$ of waste for $0.02 \mathrm{~m}^{3}$ of biodigester, the equivalent biodigester size for $13,310 \mathrm{~kg}$ of waste was estimated to be $67 \mathrm{~m}^{3}$ to produce 39,1301 of biogas daily to meet the energy needs of $\sim 100$ rural households. 


\section{Avoided Emission Calculations/Climate Change Impact Reduction}

The avoided emissions were estimated based on the biogas equivalent to the fossil fuel conversion method (B-Sustain 2013b), and $1 \mathrm{~m}^{3}$ of biogas equivalent for each of the fuels is given in Table 2. The emission factors of biogas, kerosene, LPG, kerosene, and firewood were obtained from Simon et al. (2006), which was used for the estimation of the $\mathrm{CO}_{2}$ emission. The $\mathrm{CO}_{2}$ emission reduction potential of using biogas in relation to other fuels was evaluated by subtracting the emission from the particular fuel and that from biogas.

\section{Estimation of Life Cycle Costs and Return Streams}

In order to estimate the unit cost for the produced biogas for either cooking or electricity generation will involve life cycle analysis (Lakhani et al. 2014). For this project, a 20-year life cycle was assumed for biogas generation (Tsaganakis and Papadogiannis 2006). Based on the assumption, this life cycle cost was calculated thus:

$$
\text { Life cycle cost }(L C C)=\frac{\text { Total cost }}{\text { Energy derived }}
$$

where Total Cost $=$ Fixed Costs + Variable Costs.

1. Cooking: To calculate LCC for energy derived from biogas for cooking, the assumption made is that the digester has a life cycle of 20 years and production capability of $39.13 \mathrm{~m}^{3}$ per day. It is also assumed that the digester will work for 300 days in a year.

2. Electricity generation: For the energy derived from biogas for electricity, the assumption made for the life cycle is 20 years, production capacity of 849845.57 BTU/day, and 300 days of yearly operation.

3. Digestate production: To calculate LCC for digestate from the biodigester, the assumption made is that the digester has a life cycle of 20 years and production capability of $54.26 \mathrm{~kg}$ per day, with 300 working days per year.

Table 2 Biogas equivalent to fossil fuels and firewood

\begin{tabular}{l|l|l}
\hline & Fuel & Quantity $(\mathrm{kg})$ \\
\hline & LPG & 0.45 \\
\hline $1 \mathrm{~m}^{3}$ of biogas equivalent to & Kerosene & 0.6 \\
\hline & Firewood & 3.5 \\
\hline & Furnace oil & 0.4 \\
\hline & Petrol & 0.7 \\
\hline & Diesel & 0.5 \\
\hline
\end{tabular}

Source: B-Sustain (2013b) 
The life cycle costs obtained were used to calculate the sales price based on the value added tax (VAT) of 5\%, bank interest of 25\% (assuming bank loan was secured to execute the project), sales tax of 5\% (assuming sales tax will be charged), and a profit margin of $5 \%$, which gives a sum of $40 \%$. The sales prices were estimated by calculating $40 \%$ of the life cycle costs.

\section{Business Model Formulation}

The user-centered approach represents the concept behind the business model formulation to enable coupling of technical and economic aspects of biogas production principally for rural energy supply. This also includes issues of cash flows, access to finances, and fuel switching in rural areas of Nigeria.

The formulated business model gives potential investors an overview of typical rural energy markets, target customers, and potential return streams to be earned from a biogas production business. The adapted model is an integrated one with three domains. The first domain is the upstream side or technical input, which includes planning, R\&D resources, and installation of the production process of the business that includes building of the biodigester, storage system, laying of supply pipelines, and sourcing for raw materials to be used from farms and food industries biowastes. The second domain reflects the transformation of the raw materials from the biodigester to create value for the target market. This involves anaerobic digestion to yield raw biogas and the byproduct as digestate (fertilizer), piping the biogas to connected households for cooking, and subsequently cleaning and pressurizing the biogas for electricity generation to the target customers. The last domain is the market segment of the business. This involves the marketing of biogas and digestate to target customers which include: cottage industries, residential use, commercial, and farmers.

Smallholders in rural areas usually have limited access to finance as they have to confront different challenges from bank demands, such as the complex and drawnout procedure of documentations, high bank charges, short-term nature of the credit, and disturbing problem of mortgage for security (Abdullah et al. 2015). In the same vein is the issue of fuel switching. The Nigeria household energy mix is as shown in Fig. 3, with firewood making up 56\% and sawdust being the least at $2 \%$. To increase the proportion of clean energy sources in the form of gas such as LPG and biogas will require substantial fuel switching. The current proportion of clean energy sources in the household energy mix is barely $5 \%$. This will even be worse in rural areas in Nigeria, where dependence on unclean sources such as firewood and kerosene are even more prevalent. For clean energy sources such as biogas or LPG to be more acceptable, the proposed business model takes into consideration the provision for household fuel switch, particularly in rural areas. The most used fuel stove currently in rural areas of Nigeria is based on firewood that depends on the traditional three-stone stoves or mud-built stoves. These stoves are grossly inefficient and unhealthy for humans and the environment due to the release of inimical particulate matter into the air (Akinbami and Momodu 2013). So tackling fuel 
Fig. 3 Nigeria household energy mix (Source: Ministry of Petroleum Resources 2017)

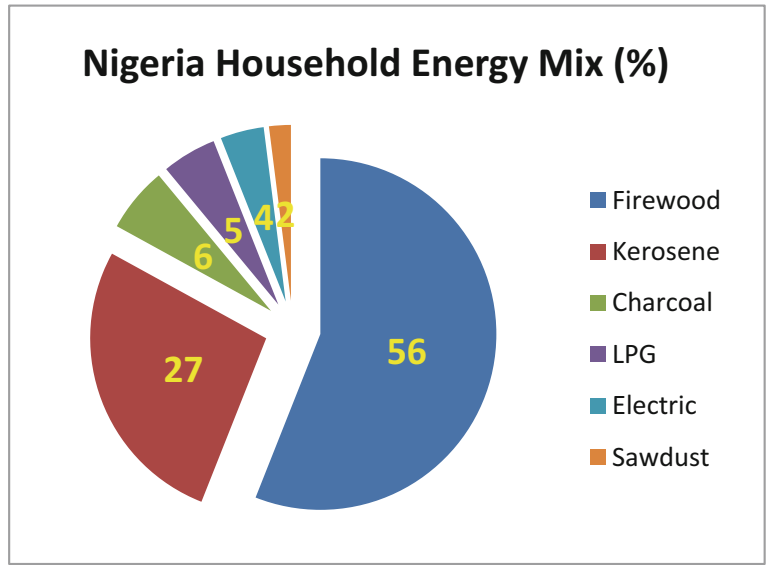

switching for rural households will involve tackling the economics of fuel and stove type, respectively. Other issues to be addressed include but not limited to access conditions to fuels, technical characteristics of cook stoves and cooking practices, cultural preferences, and health impacts (Masera et al. 2000).

\section{Results and Discussion}

This section presents the results and analysis of the study. This includes the process of scaling up laboratory experiments to the field scale, avoided emission, investment cost, variable cost stream, lifecycle cost, and return streams, as well as business model formulation.

\section{Scaled Up Biogas Production}

Scaling up the biogas production to meet energy provision consists of a system of seven tanks of biodigesters that are each sized at $9.6 \mathrm{~m}^{3}$. In this farm of biodigesters, the tanks tilted at $45^{\circ}$ will consist of a mechanical stirrer, inlet, and outlet for feeding slurry and evacuating digestate, respectively. Biogas collection will be done using gas hoses connected to the gate valve at the top of the biodigester tanks (Arnott 1985). The raw biogas will be subjected to purification, liquefaction, storage, and transportation (Ahmad et al. 2018). The purification could be done either using water scrubber and iron filings or through cryogenic processes, depending on the level of purity required, which is determined by use. The water scrubber and iron filings will be used to clean the biogas by removing $\mathrm{CO}_{2}$ and $\mathrm{H}_{2} \mathrm{~S}$ when the gas is needed only for cooking. On the other hand, cryogenic process is used when the gas purity is required at $94-99 \%$ level. This is an environmentally friendly biogas upgrading and 


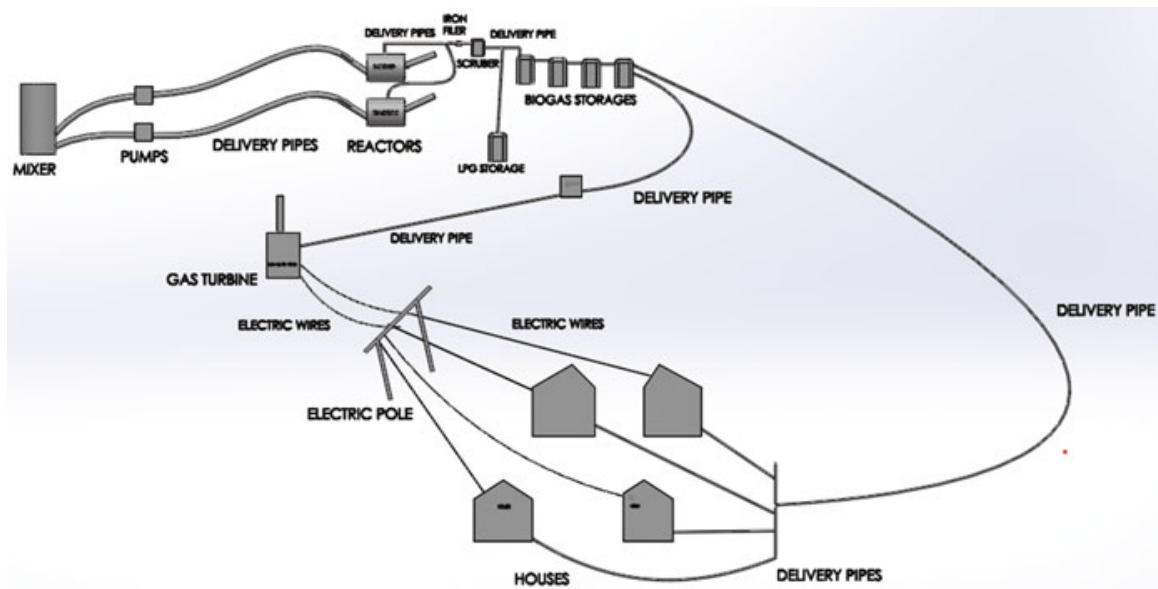

Fig. 4 Schematic layout of biogas production system for household energy and electricity generation

biomethane liquefaction system which separates pollutants and $\mathrm{CO}_{2}$ from biogas via low-temperature (Ahmad et al. 2018). The cryogenic process will be used to purify and liquefy the biogas to be produced for the reason of storage, transportation, and high energy content gas demand of some applications. Thus, it is imperative that the concentration of methane in the biogas be increased with the removal of $\mathrm{CO}_{2}$.

The gas will be stored in four interconnected fiber-glass tanks of $10 \mathrm{~m}^{3}$ each. Two fiber glass tanks will supply gas for electricity generation, while the other two fiber glass tanks will be for cooking. For safety measures, there will be an inclusion of a water-cooling system for the storage tanks and regular cleaning of the pipe holes to avoid blockages and leakages and the use of several pressure relief valves along the pipeline to control the pressure of the gas. A schematic of the biogas production system is depicted in Fig. 4.

\section{Avoided Emissions}

Utilization of energy derived from biogas technology operates to reduce GHG emissions, particularly $\mathrm{CO}_{2}$, by reducing the demand for fossil fuels and waste management (B-Sustain 2013a). The emission factors used for estimating the GHG emission from different fuel types are shown in Table 3, while Table 4 shows the total GHG emission of different fuel types. Table 5 shows that using $39.13 \mathrm{~m}^{3}$ /day of biogas produced from vegetal matter could reduce the $\mathrm{CO}_{2}$ emission of $9.69 \mathrm{~kg}$ from LPG, $37.49 \mathrm{~kg}$ from kerosene, $23.15 \mathrm{~kg}$ from diesel, and $181.65 \mathrm{~kg}$ from firewood use. Therefore, using biogas produced from waste of vegetal matter instead of LPG, kerosene, diesel, and firewood fuels is a means to mitigate the environmental impacts of $\mathrm{CO}_{2}$ and other $\mathrm{GHG}$. 
Table 3 Emission factors

\begin{tabular}{l|c|l|l|l|l}
\hline & \multicolumn{5}{l}{ Fuel type } \\
\cline { 2 - 6 } Emission factors & Biogas & LPG & Kerosene & Diesel & Firewood \\
\hline $\mathrm{CO}_{2}(\mathrm{~kg} / \mathrm{MJ})$ & 0.055 & 0.063 & 0.072 & 0.074 & 0.11 \\
\hline $\mathrm{CH}_{4}(\mathrm{~kg} / \mathrm{MJ})$ & 0.000001 & 0.000001 & 0.000003 & 0.000003 & 0.00003 \\
\hline
\end{tabular}

Source: (IPCC 2006)

Table 4 Emissions from different fuel types

\begin{tabular}{|c|c|c|c|c|c|c|}
\hline \multirow[b]{3}{*}{ Fuel type } & \multicolumn{6}{|c|}{ Gas emitted $(\mathrm{Kg})$} \\
\hline & \multicolumn{2}{|l|}{ Daily } & \multicolumn{2}{|l|}{ Annually } & \multicolumn{2}{|c|}{ For a period of 20 years } \\
\hline & $\mathrm{CO}_{2}$ & $\mathrm{CH}_{4}$ & $\mathrm{CO}_{2}$ & $\mathrm{CH}_{4}$ & $\mathrm{CO}_{2}$ & $\mathrm{CH}_{4}$ \\
\hline Biogas & 40.6 & 0.00074 & $12,178.1$ & 0.22 & $243,560.8$ & 4.5 \\
\hline LPG & 50.3 & 0.00079 & $15,086.5$ & 0.24 & $301,729.3$ & 4.8 \\
\hline Kerosene & 78.1 & 0.0032 & $23,424.2$ & 0.98 & $468,484.6$ & 19.6 \\
\hline Diesel & 63.7 & 0.0026 & $19,122.3$ & 0.77 & $382,444.9$ & 15.5 \\
\hline Firewood & 222.2 & 0.06 & $66,673.2$ & 17.86 & $1,333,466$ & 357.2 \\
\hline
\end{tabular}

Table 5 Avoided emissions from different fuel types

\begin{tabular}{l|c|l|l|l|l|r}
\hline \multirow{2}{*}{ Fuel Type } & \multicolumn{5}{l}{ Gas emitted $(\mathrm{Kg})$} & \multicolumn{2}{l}{ Annually } & \multicolumn{2}{l}{ For a period of 20 years } \\
\cline { 2 - 7 } & Daily & $\mathrm{CO}_{2}$ & $\mathrm{CH}_{4}$ & $\mathrm{CO}_{2}$ & $\mathrm{CH}_{4}$ & \multicolumn{2}{l}{$\mathrm{CO}_{2}$} & $\mathrm{CH}_{4}$ \\
\hline Biogas & 0 & 0 & 0 & 0 & 0 & 0 \\
\hline LPG & 9.7 & $5.3 \mathrm{E}-05$ & 2908.4 & 0.016 & $58,168.55$ & 0.3 \\
\hline Kerosene & 37.5 & 0.0025 & $11,246.2$ & 0.76 & $224,923.8$ & 15.1 \\
\hline Diesel & 23.2 & 0.0018 & 6944.2 & 0.55 & $138,884.1$ & 11.0 \\
\hline Firewood & 181.7 & 0.059 & $54,495.3$ & 17.62 & $1,089,906$ & 352.7
\end{tabular}

\section{Investment Cost and Variable Cost Stream}

The cost stream, as shown in Table 6, itemizes the cost of materials to be used for the construction of $67 \mathrm{~m}^{3}$ biodigester, including its civil works, the pipelines for gas evacuation and distribution, and the storage tank. The materials include stainless steel, copper pipes for connections, different sizes of valves, scrubber and iron filings, compressor, LPG cylinder, gas turbine, storage tanks, single burner cooking stoves, and rubber hoses. For purer gas needs, the materials will include cryogenic equipment.

\section{Life Cycle Costs and Return Streams}

Based on the production of biogas from the biodigesters, life cycle costs (LCC) were estimated for cooking, electricity generation, and digestate production in three different scenarios. The first scenario, called A, considered the production of 
Table 6 Cost stream

\begin{tabular}{|c|c|c|c|}
\hline Item description & $\begin{array}{l}\text { Estimated unit } \\
\text { cost }\end{array}$ & $\begin{array}{l}\text { Estimated } \\
\text { quantity }\end{array}$ & Amount (A) \\
\hline \multicolumn{4}{|l|}{ Fixed costs } \\
\hline Stainless steel $9.6 \mathrm{~m}^{3}$ tanks & 1000,000 & 7 & $7,000,000$ \\
\hline Different sizes of connecting tubes & 500 & 160 & 80,000 \\
\hline Different sizes of valves & 5000 & 160 & 800,000 \\
\hline Cryogenic equipment & $3,500,000$ & 2 & $7,000,000$ \\
\hline Land cost and site construction & $1,500,000$ & 4 & $6,000,000$ \\
\hline Transportation & 2,000 & 12 & 24,000 \\
\hline Storage tanks & 200,000 & 18 & $3,600,000$ \\
\hline $\begin{array}{l}\text { Average labor (skilled and unskilled) } \\
\text { costs }\end{array}$ & 8,000 & 20 & 160,000 \\
\hline Purchase of pressure relief valves & 1,000 & 10 & 10,000 \\
\hline Purchase of copper pipes & 6,000 & 2 & 12,000 \\
\hline $\begin{array}{l}\text { Construction of biogas burner cooking } \\
\text { stoves }\end{array}$ & 8,000 & 100 & 800,000 \\
\hline \multirow[t]{2}{*}{ Gas distribution lines } & 1000 & 500 & 500,000 \\
\hline & & & $25,986,000$ \\
\hline \multicolumn{4}{|l|}{ Variable cost } \\
\hline Substrate collection & 399,286 & 1 & 399,286 \\
\hline Sample analysis & 8000 & 1 & 8,000 \\
\hline Operation and maintenance costs & $2,000,000$ & 1 & $2,000,000$ \\
\hline Salvage cost & 700,000 & 1 & 700,000 \\
\hline Total & & & $29,093,285.60$ \\
\hline
\end{tabular}

digestate and biogas for cooking only, in which the LCC are $\$ 0.13 / \mathrm{kg}(\mathbb{4} 4.67 / \mathrm{kg})$ and $\$ 0.14 / \mathrm{m}^{3}\left(\mathrm{~N} 50.50 / \mathrm{m}^{3}\right)$, respectively. The second scenario B is the production of the digestate and biogas for electricity, while the last scenario $\mathrm{C}$ considers the production of digestate, $50 \%$ biogas for cooking and $50 \%$ biogas for electricity. These life cycle costs enable the cost comparison analysis of various scenarios (Table 7).

Theoretically, the investment cost is estimated as $\mathrm{N} 29.1$ million, while the return streams at different scenarios are the same, which is $\mathbb{N} 40.74$ million with a profit

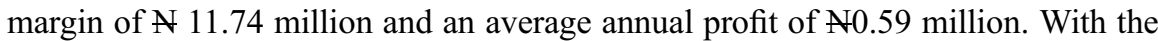
positive difference between the LCC and the return stream generated, the biogas project shows good performance with hope the business will allow for its smooth operation to enable quick cost recovery.

\section{Business Model Formulation}

The concept proposed for the rural energy biogas business, based on user-centered design, is diagrammatically shown in both Figs. 5 and 6, respectively. Figure 5 shows a simplified schematic diagram of the business model that mimics what is 
Table 7 LCC and return stream

\begin{tabular}{|c|c|c|c|c|}
\hline \multicolumn{5}{|l|}{ Scenario A } \\
\hline & LCC (A/kg) & $\begin{array}{l}\text { Sales price }(\mathrm{A} / \mathrm{l} \\
\text { kg) }\end{array}$ & $\begin{array}{l}\text { Quantity } \\
\text { (tonnes) }\end{array}$ & $\begin{array}{l}\text { Revenue (A) } \\
\text { (million) }\end{array}$ \\
\hline Cooking & 50.50 & 70.69 & 288.1 & 20.37 \\
\hline Digestate & 44.67 & 62.54 & 325.6 & 20.37 \\
\hline Total & & & & 40.74 \\
\hline \multicolumn{5}{|l|}{ Scenario B } \\
\hline & LCC & Sales price & Quantity & $\begin{array}{l}\text { Revenue (N) } \\
\text { (million) }\end{array}$ \\
\hline $\begin{array}{l}\text { Electricity } \\
\text { generation }\end{array}$ & $\begin{array}{l}0.00285(\mathrm{~N} / \\
\mathrm{BTU})\end{array}$ & $0.004(\mathrm{~A} / \mathrm{BTU})$ & 5 million BTU & 20.37 \\
\hline Digestate & $44.67(\mathrm{~N} / \mathrm{kg})$ & $62.54(\mathrm{~N} / \mathrm{kg})$ & 325.6 tonnes & 20.37 \\
\hline Total & & & & 40.74 \\
\hline \multicolumn{5}{|l|}{ Scenario C } \\
\hline & LCC & Sales price $(\mathrm{N})$ & Quantity & $\begin{array}{l}\text { Revenue (N) } \\
\text { (million) }\end{array}$ \\
\hline Cooking & $\mathrm{A} 67.33 / \mathrm{kg}$ & 94.25 & 144.04 tonnes & 13.58 \\
\hline $\begin{array}{l}\text { Electricity } \\
\text { generation }\end{array}$ & $\begin{array}{l}\text { A } 0.0038 / \\
\text { BTU }\end{array}$ & 0.0053 & 2 million BTU & 13.58 \\
\hline Digestate & N 29.79/kg & 41.70 & 325.6 tonnes & 13.58 \\
\hline Total & & & & 40.74 \\
\hline
\end{tabular}

Fig. 5 Simplified schematic diagram of the biogas business model

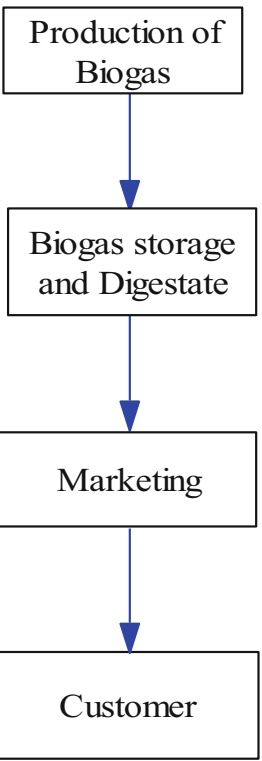




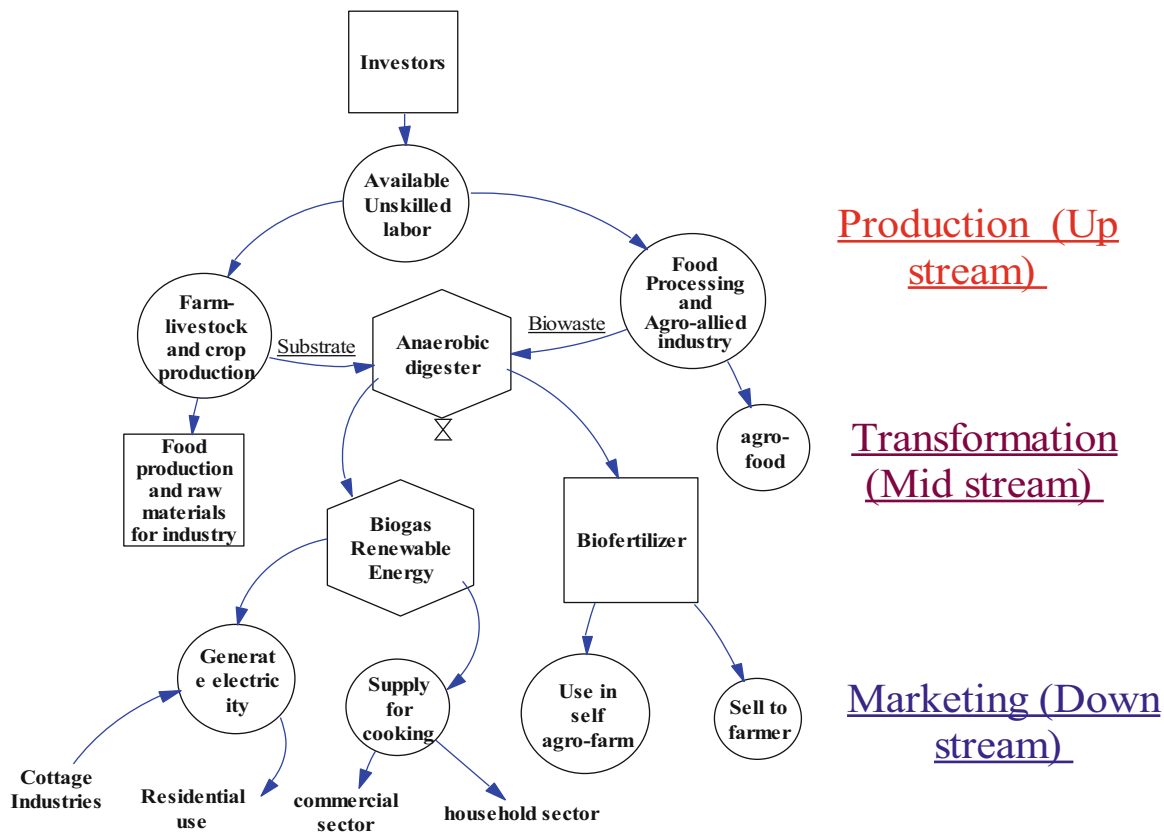

Fig. 6 Schematic diagram of the adopted business model. Source: Adapted from Yousuf et al. (2017)

obtained in traditional vertically integrated electric power systems (Walsh and Todeva 2005). Both diagrams show three distinct operations of technical inputs, storage of biogas and digestate, as well as marketing. The first domain contains most of the investment cost segment of the model. The cost stream in the business model involves investment in livestock and crop farming, food processing, agro-allied industry, and biodigester construction, while the biogas yield and bio-fertilizer will generate the return stream for the business. From the perspective of the investors, the financial feasibility of the biogas business would be assessed based on its return and cost streams as well as its ability to make profit. In Nigeria, rural areas are mostly faced with challenges in fuel switching, access to finances, and cash flows. For this project, in order to make the business model operational, the issue of fuel switching is addressed. Addressing this challenge involves adopting a user-centered approach that combines different types of business models. At inception, a niche business model would be introduced to incentivize the first few households that adopt (early adopters) the use of biogas as an energy source, where a single gas stove burner would be given to them free but have to buy the gas to be used. For other households (mid to late adopters), the razor and blade business model would be introduced, where the users will have to buy the gas stoves at graduated subsidized prices and still also have to purchase the gas for use. 


\section{Conclusions and Recommendations}

Global climate change impact needs to be addressed strategically using local actions. One of such strategy is the use of low-carbon energy resource to meet energy demand. Energy supply in Nigeria is at best erratic, and this is even more pronounced in the rural areas. In addition, Nigeria, particularly her rural populace, is among the most vulnerable to global climate change impact; this is even more aggravated by Nigeria's dependence on fossil fuel usage as well as poor waste management, which two, contribute significantly to greenhouse gas emissions and influences climate change impact significantly. Using waste conversion option through biogas production to meet rural household energy demand is a local action to contribute to the global strategy. Presented are both technical and business model for using biogas production as a means of waste management measure and energy supply source. The study shows that, theoretically, scaling up of laboratory experiments for biogas production through the process of bio-waste anaerobic digestion is not only possible but also comes with a positive difference in climate change impact reduction as well as between costs and returns. First, the project will achieve avoided emissions to reduce climate change impact, which is put at $58,168.55 \mathrm{~kg}$, $224,923.8 \mathrm{~kg}, 138,884.1 \mathrm{~kg}$, and 1,089,906 kg, respectively, for LPG, kerosene, diesel, and firewood. In terms of costs and returns, three different scenarios are looked into, namely, Scenario A involves just cooking using the biogas produced for cooking and selling of the digestate as bio-fertilizer; Scenario B, involving using the biogas produced for electricity generation, and selling of the digestate; and Scenario C, cooking, electricity generation, and digestate sales are considered. The total cost estimated for starting the project is approximately $\mathrm{N} 29.1 \mathrm{million}$, and the returns stream is estimated at $\mathrm{N} 40.74$ million. This gives a profit margin of $\mathrm{N} 11.64$ million for the 20-year life cycle and an average yearly profit of $\mathrm{N} 0.59$ million. It is important to note that each of the scenarios presented the same total cost though the LCC and sales price pathways were different. Biogas energy production could be effective to transforming the rural economy. Another aspect of interest that needs to be further investigated is that the $\mathrm{CO}_{2}$ got from cryogenic processes could be channeled. This will generate some income while also removing $\mathrm{CO}_{2}$ from the atmosphere. It is further recommended that an actual pilot scale be done with data to verify the theoretical estimation made in this study.

\section{References}

Abdullah DZ, Khan SA, Jebran K, Ali A (2015) Agricultural credit in Pakistan: past trends and future prospects. J Appl Environ Biol Sci 5:178-188

Adepoju TD (2019) Biogas generation using vegetal matter via anaerobic digester. A Bachelor's degree thesis. Obafemi Awolowo University, Ile-Ife

Ahmad NE, Mel M, Sinaga N (2018) Design of liquefaction process of biogas using Aspen HYSYS simulation. J Adv Res Biofuel Bioenergy 2:10-15

Ahmadu TO, Folayan CO, Yawas DS (2009) Comparative performance of cow dung and chicken droppings for biogas production. Niger J Eng 16(1):154-164 
Akinbami CA, Momodu AS (2013) Health and environmental implications of rural female entrepreneurship practices in Osun state Nigeria. Ambio 42(5):644-657

Aransiola EF, Ojumu TV, Oyekola OO, Madzimbamuto TF, Ikhu-Omoregbe DIO (2014) A review of current technology for biodiesel production: state of the art. Biomass Bioenergy 61:276-297

Arent DJ, Tol RS, Faust E, Hella JP, Kumar S, Strzepek KM, Tóth FL, Yan D, Abdulla A, Kheshgi H, Xu H (2015) Key economic sectors and services. In: Climate change 2014 impacts, adaptation and vulnerability: part a: global and sectoral aspects. Cambridge University Press, Cambridge, pp 659-708. 2010

Arnott M (1985) Biogas/biofertilizer business handbook (no. PB-87-158937/XAB; PC/ICE/R-48). Peace Corps, Washington, DC. Information Collection and Exchange

Arora SM, Linton JA (2011) Mississippi renewable energy and energy efficiency report. A snap shot of related activities in the state of Mississippi (no. DOE-MTA-85002). Mississippi Technology Alliance, Jackson

Arsova L (2010) Anaerobic digestion of food waste: current status, problems and an alternative product. Department of Earth and Environmental Engineering Foundation of Engineering and Applied Science Columbia University

Bello IA, bin Ismail MN, Kabbashi NA (2016) Solid waste management in Africa: a review. Int J Waste Resour 6(2):1-4

Bharadwaj A, Yadav D, Varshney S (2015) Non-biodegradable waste- its impact and safe disposal L. Int J Adv Technol Eng Sci III:184-191

Bölük G, Mert M (2014) Fossil \& renewable energy consumption, GHGs (greenhouse gases) and economic growth: evidence from a panel of EU (European Union) countries. Energy 74:439-446

Brown VJ (2006) Biogas a bright idea for Africa. Environ Health Perspect 114:A300-A303

B-Sustain (2013a) Environmental and social benefits of biogas technology. Retrieved from: http:// www.bsustain.in/faqs.html. Accessed July 2019

B-Sustain (2013b) Biogas equivalent to fossil fuels and its emission comparison. Retrieved from: http://www.bsustain.in/faqs.html. Accessed July 2019

Budiyono B, Widiasa IN, Johari S, Sunarso S (2014) Increasing biogas production rate from cattle manure using rumen fluid as inoculums. Int J Sci Eng 6(1):31-38

Budzianowski WM, Brodacka M (2017) Biomethane storage: evaluation of technologies, end uses, business models, and sustainability. Energy Convers Manag 141:254-273

Christy EM, Sampson NM, Edson LM, Anthony IO, Michael S (2013) Microbial anaerobic digestion (bio-digesters) as an approach to the decontamination of animal wastes in pollution control and the generation of renewable energy. Int J Environ Res Public Health 10:4390-4417

Elhasan MMAA, Abdalla IF, Ibrahim AAA (2015) Economics of onion production under cooperative and private schemes in Khartoum North, Sudan (No. 15/05). NAF International Working Paper Series

Guerrero LA, Maas G, Hogland W (2013) Solid waste management challenges for cities in developing countries. Waste Manag 33(1):220-232

Isiaka T (2017) Challenges of waste management in Lagos. Susty Vibes

Jiang X, Sommer SG, Christensen KV (2011) A review of the biogas industry in China. Energy Policy 39(10):6073-6081

Jun H, Xiang H (2011) Development of circular economy is a fundamental way to achieve agriculture sustainable development in China. Energy Procedia 5:1530-1534

Krich K, Augenstein D, Batmale J, Benemann J, Rutledge B, Salour D (2005) Biomethane from dairy waste: a sourcebook for the production and use of renewable natural gas in California. Western United Dairymen. Available at: http://www.suscon.org/cowpower/biomethaneSourcebook/Full_ Report.pdf

Lakhani R, Doluweira G, Bergerson J (2014) Internalizing land use impacts for life cycle cost analysis of energy systems: a case of californias photovoltaic implementation. Appl Energy 116:253-259

Levenspiel O (1999) Chemical reaction engineering. Ind Eng Chem Res 38(11):4140-4143

Madriz-Vargas R, Bruce A, Watt M (2018) The future of community renewable energy for electricity access in rural Central America. Energy Res Soc Sci 35:118-131 
Manyi-Loh CE, Mamphweli SN, Meyer EL, Okoh AI, Makaka G, Simon M (2013) Microbial anaerobic digestion (bio-digesters) as an approach to the decontamination of animal wastes in pollution control and the generation of renewable energy. Int J Environ Res Public Health 10(9):4390-4417

Margolis R, Zuboy J (2006) Nontechnical barriers to solar energy use: review of recent literature (No. NREL/TP-520-40116). National Renewable Energy Laboratory (NREL), Golden

Masera OR, Saatkamp BD, Kammen DM (2000) From linear fuel switching to multiple cooking strategies: a critique and alternative to the energy ladder model. World Dev 28(12):2083-2103

Ministry of Petroleum Resources (2017) National gas policy approved by FEC. Assessed from http://www.petroleumindustrybill.com/wpcontent/uploads/2017/06/National-Gas-PolicyApproved-By-FEC-in-June-2017.pdf. 27 May 2019

Misi SN, Forster CF (2002) Semi-continuous anaerobic co-digestion of agro-wastes. Environ Technol 23(4):445-451

Natural Resources Conservation Service (2004) Anaerobic digester-controlled temperature. 2004Code366 Natural resources conservation service, Conservation practice standard. Available at http://efotg.sc.egov.usda.gov//references/public/CA/366std-9-04.pdf

Neba FA, Asiedu NY, Addo A, Morken J, Østerhus SW, Seidu R (2020) Biodigester rapid analysis and design system (B-RADeS): a candidate attainable region-based simulator for the synthesis of biogas reactor structures. Comput Chem Eng 132:106607

Ogundipe A, Akinyemi O, Alege PO (2014) Energy supply and climate change in Nigeria. J Environ Earth Sci 4:14

Ogwueleka TC (2009) Municipal solid waste characteristics and Management in Nigeria. Iran J Environ Health Sci Eng 6(3):173-180

Otun T, Ojo O, Ajibade F (2015) Evaluation of biogas production from the digestion and co-digestion of animal waste, food waste and fruit waste. Int J Energy Environ Res 3(3):12-24

Rajendran K, Aslanzadeh S, Taherzadeh JM (2012) Household biogas digesters- a review. Energies 5(8):2911-2942

Rea J (2014) Kinetic modeling and experimentation of anaerobic digestion. Doctoral dissertation, Massachusetts Institute of Technology

Redström J (2006) Towards user design? On the shift from object to user as the subject of design. Des Stud 27(2):123-139

Riuji LC (2005) Research on anaerobic digestion of organic solid waste at household level in Dar Es Salaam, Tanzania. Doctoral dissertation, ARDHI University

Roos KF, Martin JB, Moser MA (2004) AgStar handbook: a manual for developing biogas systems at commercial farms in the United States. EPA-430-B-97-015. USEPA, Washington, DC. Available at: http://www.epa.gov/agstar/documents/AgSTAR-handbook.pdf

Schaeffer R, Szklo AS, de Lucena AFP, Borba BSMC, Nogueira LPP, Fleming FP, Troccoli A, Harrison M, Boulahya MS (2012) Energy sector vulnerability to climate change: a review. Energy 38(1):1-12

Simon Eggelston, Leandro Buendia, Kyoko Miwa, Todd Ngara, Kiyoto Tanabe (2006) Guidelines for national greenhouse gas inventories. The Institute for Global Environmental Strategies (IGES) for the IPCC, Tokyo, Japan

Solaun K, Cerdá E (2019) Climate change impacts on renewable energy generation. A review of quantitative projections. Renew Sust Energ Rev 116:109415

Sridevi D, Ramanujam RA (2012) Biogas generation in a vegetable waste anaerobic digester: an analytical approach. Res J Recent Sci 1(3):41-47

Stan C, Collaguazo G, Streche C, Apostol T, Cocarta D (2018) Pilot-scale anaerobic co-digestion of the OFMSW: improving biogas production and startup. Sustainability 10(6):1939

Tsaganakis KP, Papadogiannis C (2006) Technical and economic evaluation of the biogas utilization for energy production at Iraklio municipality, Greece. Energy Convers Manag 47:844-857

Twidell J, Weir T (2005) Biomass and biofuels. In: Renewable energy resources, 2nd edn. Spon, London, pp 351-399 
Vanguard (2017) Nigeria generated $24 \mathrm{~m}$ tonnes of waste more than rice in 18 states in $2016-$ reports. Assessed from https://www.vanguardngr.com/2017/08/nigeria-generated-24m-tonneswaste-rice-18-states-2016-reports/. 16th Aug 2019

Walsh PR, Todeva E (2005) Vertical and Horizontal Integration in the Utilities Sector: the case of RWE. Unpublished paper

WHO (2015) Residential heating with wood and coal: health impacts and policy options in Europe and North America. World Health Organisation, Copenhagen, Denmark

Yadoo A, Cruickshank H (2012) The role for low carbon electrification technologies in poverty reduction and climate change strategies: a focus on renewable energy mini-grids with case studies in Nepal, Peru and Kenya. Energy Policy 42:591-602

Yousuf A, Sultana S, Monir M, Karim A, Rahmaddulla S (2017) Social business models for empowering the biogas technology. Energy sources. Part B Economics, planning and policy. 12:99-109

Ziyan T, Xiaohua L (2014) Design and optimization principles of biogas reactors in large scale applications. In: Reactor and process design in sustainable energy technology. Elsevier, Amsterdam, Netherlands, pp 99-134

Open Access This chapter is licensed under the terms of the Creative Commons Attribution 4.0 International License (http://creativecommons.org/licenses/by/4.0/), which permits use, sharing, adaptation, distribution and reproduction in any medium or format, as long as you give appropriate credit to the original author(s) and the source, provide a link to the Creative Commons license and indicate if changes were made.

The images or other third party material in this chapter are included in the chapter's Creative Commons license, unless indicated otherwise in a credit line to the material. If material is not included in the chapter's Creative Commons license and your intended use is not permitted by statutory regulation or exceeds the permitted use, you will need to obtain permission directly from the copyright holder.

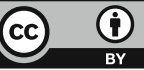

